\title{
The Effect of Oral Nifedipine versus Parenteral Magnesium Sulfate and Ritodrine for Tocolysis in Patients with Threatened Preterm Labor: A Randomized Controlled Trial
}

\author{
Safwat A. Salman' ${ }^{1}$, Dina Habibi, ${ }^{1}$ Mohamed Atef ${ }^{2}$, Ahmed M. Abbas ${ }^{1}$ \\ ${ }^{1}$ Department of Obstetrics \& Gynecology, Faculty of Medicine, Assiut University, Assiut, Egypt \\ ${ }^{2}$ Department of Obstetrics \& Gynecology, Sohag Teaching Hospital, Sohag, Egypt \\ Email:bmr90@hotmail.com
}

How to cite this paper: Salman, S.A., Habib, D., Atef, M. and Abbas, A.M. (2019) The Effect of Oral Nifedipine versus Parenteral Magnesium Sulfate and Ritodrine for Tocolysis in Patients with Threatened Preterm Labor: A Randomized Controlled Trial. Open Journal of Obstetrics and Gynecology, 9, 1142-1150.

https://doi.org/10.4236/ojog.2019.98110

Received: July 12, 2019

Accepted: August 10, 2019

Published: August 13, 2019

Copyright $\odot 2019$ by author(s) and Scientific Research Publishing Inc. This work is licensed under the Creative Commons Attribution International License (CC BY 4.0).

http://creativecommons.org/licenses/by/4.0/

\begin{abstract}
Background: Preterm labor is a serious cause of neonatal morbidity and mortality. This study aims to compare the effects of nifedipine, Magnesium sulfate and ritodrine as tocolytic drugs in patients presented with threatened preterm labor. Patients and Methods: The current study was randomized controlled trial conducted in Sohag Teaching Hospital between November 2015 and September 2016. Patients were divided into: Group A: 101 patients received intravenous ritodrine infusion; Group B: 101 patients received intravenous magnesium sulfate; Group C: 101 patients received oral nifedipine. Different maternal and neonatal outcomes were assessed. Results: The baseline criteria were homogenous among the study groups with no statistically significant differences. There is no difference between each other group regarding the need for additional tocolysis or the rate of recurrence of labour pains. Nifedipine was associated with the least length of hospital stay. There is no difference between all groups regarding the rate of preterm delivery before full steroid dose ( $p>0.05)$. However, nifedipine group was the least one in the rate of occurrence of preterm delivery within 7 days from initiation of tocolytic therapy. Similarly, nifedipine group was associated with higher gestational age at delivery and significant prolongation of pregnancy than the other groups. Conclusion: Oral nifedipine use was associated with less recurrence of labor pains, less need for additional tocolysis, less duration of hospital stay, and more patient satisfaction in patients with threatened preterm labour.
\end{abstract}

\section{Keywords}

Tocolysis, Preterm Labour, Nifedipine, Ritodrine 


\section{Introduction}

Preterm labour is defined as regular contractions of the uterus resulting in changes in the cervix that start before 37 weeks of pregnancy. Changes in the cervix include effacement and dilatation. When birth occurs between 20 weeks of pregnancy and 37 weeks of pregnancy it is called preterm birth [1]. Factors that increase the risk of preterm birth include the following: a previous preterm birth, short cervix, short interval between pregnancies, previous surgery on the cervix or the uterus, pregnancy complications such as multiple pregnancy and vaginal bleeding, low pregnancy weight, smoking during pregnancy and drug abuse during pregnancy [1].

The risk of neonatal mortality and morbidity is low after 34 weeks of gestation; although a trial of acute tocolysis may be initiated; aggressive tocolytic therapy is generally not recommended beyond 34 weeks, due to potential maternal complications [2]. Between 24 and 33 weeks' gestation, benefits of tocolytic therapy are generally accepted to outweigh the risk of maternal and/or fetal complications and these agents should be initiated provided no contraindications exist.

The administration of steroids is recommended in the absence of clinical infection whenever the gestational age is between 24 and 34 weeks. An attempt should be made to delay delivery for a minimum of 12 hours to obtain the maximum benefits of antenatal steroids. However, a randomized clinical trial by Porto et al. showed that treatment with corticosteroids at 34 - 36 weeks of pregnancy does not reduce the incidence of respiratory disorders in newborn infants [3].

Magnesium sulfate is widely used as the primary tocolytic agent; common maternal side effects include flushing, nausea, headache, drowsiness, and blurred vision. The mother should be monitored for toxic effects, such as respiratory depression or even cardiac arrest that can occur at supratherapeutic levels. In addition, magnesium sulfate readily crosses the placenta and may lead to respiratory and motor depression of the neonate [4].

Nifedipine, a calcium channel blocker, is commonly used to treat high blood pressure and heart disease because of its ability to inhibit contractility in smooth muscle cells by reducing calcium influx into cells. Consequently, nifedipine has emerged as an effective and safe alternative tocolytic agent for the management of preterm labor. Despite its unlabeled status, several randomized studies have shown that the use of nifedipine in comparison with other tocolytic is associated with a more frequent successful prolongation of pregnancy, resulting in significantly fewer admissions of newborns to the neonatal intensive care unit, and may be associated with a lower incidence of RDS, necrotizing enterocolitis, and intraventricular hemorrhage [4].

Ritodrine is a beta-sympathomimetic drug that is frequently used for the prevention of preterm birth. One of the most important side-effects of ritodrine is pulmonary edema [5]. 
This study aims to evaluate the effects of nifedipine, Magnesium sulfate and ritodrine as tocolytic drugs in patients presented with threatened preterm labor.

\section{Patients and Methods}

The current study was randomized controlled trial conducted in Sohag Teaching Hospital between November 2015 and September 2016. The institutional ethical review board approved the study protocol. An informed written consent has been obtained from those patients who will participate in the study.

\subsection{Inclusion Criteria}

1) Singleton pregnancy

2) Gestational age between 24 - 36 weeks.

3) Symptoms such as low backache, cramping, pelvic pressure, excessive vaginal discharge and vaginal spotting.

4) Regular frequent uterine contractions at least of 30 seconds duration at a rate of more than $4 / 20$ minutes.

5) Cervical changes: dilatation less than $3 \mathrm{~cm}$, effacement less than $50 \%$.

6) Intact membranes.

\subsection{Exclusion Criteria}

1) Cervical changes: dilatation more than $3 \mathrm{~cm}$, effacement more than $50 \%$ (patient in active labour).

2) Rupture of fetal membranes.

3) Active vaginal bleeding and placental abruption.

4) Chorioamnionitis and intrauterine infection.

5) Fetal conditions: fetal demise or distress, lethal congenital or chromosomal abnormalities.

6) Contraindications to Tocolysis for treatment of preterm labor.

\subsection{Allocation and Concealment}

All patients who presented to the hospital and meet the listed inclusion and exclusion criteria were invited to participate in the study.

Patients were divided into:

Group A: 101 patients received intravenous ritodrine infusion.

Group B: 101 patients received intravenous magnesium sulfate.

Group C: 101 patients received oral nifedipine.

\subsection{Randomization}

Patients were randomly allocated using computer generated random number tables and opaque sealed envelopes containing the participants' group allocation. The envelopes were prepared and sent to an assigned nurse, who opens each envelope just on admission. 


\subsection{Sample Size}

The calculated sample size is 303 cases divided into three groups, 101 women in each group. The sample size was calculated using $G^{*}$ power software 3.1.9.2., based on the following assumptions: Main outcome variable is: efficacy (mean number of days of prolongation of pregnancy) of nifedipine, ritodrine and magnesium sulfate drugs in management of preterm labor. Main statistical test is one way ANOVA test to detect difference among the three independent groups of women. Alpha error $=0.05$ and the Power was adjusted at $80 \%$. Effect size $($ minimum $)=0.18$ (estimated based on previous literature where the difference in efficacy of drugs ranged from $10 \%-40 \%)$.

\subsection{Intervention}

Group A: Received ritordine $50 \mathrm{mg}$ (1 ampoule) in $500 \mathrm{ml}$ dextrose $5 \%$, starting by $50 \mathrm{microgram} / \mathrm{minute}$ and increased by 50 microgram every $10 \mathrm{mi}$ nutes until cessation of uterine contractions. The infusion was continued for 12 hours after cessation of uterine contractions. The infusion was stopped if pulse $>$ 120 beats per minute, Systolic $\mathrm{Bp}>180 \mathrm{mmHg}$, diastolic $\mathrm{Bp}<40 \mathrm{mmHg}$, fetal heart rate $>200$ beats per minute, or persistent chest pain.

Group B: Received Magnesium sulfate infusion. Loading dose is 4 gram (4 ampoules) over 15 minutes to avoid cardiac and respiratory depression. The infusion then continued at a rate of 1 gram per hour, increased up to 4 gram if no response. Infusion is stopped if respiratory rate less than $16 \mathrm{cycle} / \mathrm{m}$, urine output less than $30 \mathrm{ml} /$ hour or sluggish knee jerk.

Group C: Received Nifedipine, given as $20 \mathrm{mg}$ (1 tablet) orally until uterine contractions subside, with Blood pressure monitoring.

Initial response was defined if uterine contractions were suppressed within 2 hours of tocolytic treatment. Treatment continued until contractions stopped for 24 hours, maximum doses were attained without response; unacceptable side effects occurred or labor proceeded. Successful treatment was defined as cessation of contractions observed for 24 hours and no further cervical changes. Tocolytic failure was defined as the persistence of symptomatic uterine contractions despite maximal attainable doses of therapy, rupture of previously intact membranes, or occurrence of severe side effects necessitating discontinuation of therapy.

Patients with successful treatment were put under observation for another 24 hours without additional treatment then discharged on no maintenance therapy. All patients received $24 \mathrm{mg}$ I.M. dexamethasone divided to 4 doses $6 \mathrm{mg} / 12$ hours to promote fetal lung maturation.

Study outcomes included the need for additional tocolysis, the rate of recurrence of labor pains, the adverse drug reactions, the length of hospital stay, the rate of occurrence of preterm birth, the gestational age at delivery, the mean birth weight, the rate of prolongation of pregnancy, and the rate of adverse neonatal outcomes. 


\subsection{Statistical Analysis}

Date entry and data analysis were done using SPSS version 19 (Statistical Package for Social Science). Data were presented as mean and standard deviation. Chi-square test was used to compare between qualitative variables. ANOVA and Krystal Wallis tests were used to compare between quantitative variables. $\mathrm{P}$-value considered statistically significant when $\mathrm{P}<0.05$.

\section{Results}

The study included 303 patients (101 in each arm). The baseline criteria were homogenous among the study groups with no statistical significant differences (Table 1). No difference regarding the maternal age, parity, previous number of abortions and gestational age at admission.

Table 2 shows the maternal outcomes in the study groups. No difference between each other group regarding the need for additional tocolysis or the rate of recurrence of labour pains. Adverse drug reactions for the ritodrine group were significantly higher; 57 patients $(56.4 \%)$ followed by the magnesium sulfate group; 23 patients $(22.8 \%)$ and the nifedipine group; 12 patients $(11.9 \%)(\mathrm{p}<$ 0.001 for both).

The mean length of hospital stay for the ritodrine group was $11.57 \pm 10.34$ days, versus $15.43 \pm 11.81$ days for the magnesium sulfate group and $8.79 \pm 7.08$ days for the nifedipine group. Nifedipine was associated with the least length of hospital stay.

Table 3 shows the neonatal outcomes in the study groups. No difference between all groups regarding the rate of preterm delivery before full steroid dose

Table 1. Baseline criteria of the study participants.

\begin{tabular}{|c|c|c|c|c|c|c|}
\hline & $\begin{array}{l}\text { Ritodrine } \\
(\mathrm{n}=101)\end{array}$ & $\begin{array}{l}\text { Mg sulphate } \\
(\mathrm{n}=101)\end{array}$ & $\begin{array}{l}\text { Nifedipine } \\
(\mathrm{n}=101)\end{array}$ & $P$ - value ${ }^{1}$ & $P$ - value ${ }^{2}$ & $P$ - value ${ }^{3}$ \\
\hline \multicolumn{7}{|l|}{ Age (years): } \\
\hline Mean \pm SD & $24.54 \pm 4.83$ & $24.47 \pm 4.97$ & $25.44 \pm 4.83$ & \multirow{2}{*}{0.879} & \multirow{2}{*}{0.175} & \multirow{2}{*}{0.137} \\
\hline Range & $16.0-39.0$ & $12.0-38.0$ & $17.0-36.0$ & & & \\
\hline \multicolumn{7}{|l|}{ Parity: } \\
\hline Mean \pm SD & $1.28 \pm 1.69$ & $1.10 \pm 1.48$ & $1.34 \pm 1.47$ & \multirow{2}{*}{0.463} & \multirow{2}{*}{0.375} & \multirow{2}{*}{0.082} \\
\hline Range & $0.0-10.0$ & $0.0-6.0$ & $0.0-9.0$ & & & \\
\hline \multicolumn{7}{|l|}{ Abortions: } \\
\hline Mean \pm SD & $0.46 \pm 0.89$ & $0.45 \pm 0.78$ & $0.50 \pm 0.77$ & \multirow{2}{*}{0.599} & \multirow{2}{*}{0.274} & \multirow{2}{*}{0.541} \\
\hline Range & $0.0-4.0$ & $0.0-4.0$ & $0.0-3.0$ & & & \\
\hline \multicolumn{7}{|c|}{$\begin{array}{l}\text { Gestational age: } \\
\text { (weeks) }\end{array}$} \\
\hline Mean \pm SD & $31.68 \pm 2.57$ & $31.07 \pm 2.59$ & $31.39 \pm 2.66$ & \multirow{2}{*}{0.093} & \multirow{2}{*}{0.555} & \multirow{2}{*}{0.283} \\
\hline Range & $25.0-36.0$ & $26.0-35.0$ & $24.0-34.0$ & & & \\
\hline
\end{tabular}

P-value ${ }^{1}$ : for comparison between ritodrine and magnisium sulphate. P-value ${ }^{2}$ : for comparison between ritodrine and nifedipine. $\mathbf{P}$-value ${ }^{3}$ : for comparison between nifedipine and magnisium sulphate. 
Table 2. Maternal outcomes of the study participants.

\begin{tabular}{|c|c|c|c|c|c|c|}
\hline & $\begin{array}{l}\text { Ritodrine } \\
(n=101)\end{array}$ & $\begin{array}{l}\text { Mg sulphate } \\
(\mathrm{n}=101)\end{array}$ & $\begin{array}{l}\text { Nifedipine } \\
(\mathrm{n}=101)\end{array}$ & P-value ${ }^{1}$ & P-value ${ }^{2}$ & P-value ${ }^{3}$ \\
\hline \multicolumn{7}{|c|}{$\begin{array}{l}\text { Need for additional } \\
\text { tocolysis: }\end{array}$} \\
\hline Yes & $36(35.6 \%)$ & $41(40.6 \%)$ & $33(32.7 \%)$ & \multirow{2}{*}{0.469} & \multirow{2}{*}{0.656} & \multirow{2}{*}{0.243} \\
\hline No & $65(64.4 \%)$ & $60(59.4 \%)$ & $68(67.3 \%)$ & & & \\
\hline \multicolumn{7}{|c|}{$\begin{array}{l}\text { Recurrence of } \\
\text { Labour pains: }\end{array}$} \\
\hline Yes & $41(40.6 \%)$ & 45 (44.6\%) & $37(36.6 \%)$ & \multirow[b]{2}{*}{0.569} & \multirow[b]{2}{*}{0.563} & \multirow[b]{2}{*}{0.252} \\
\hline No & $60(59.4 \%)$ & $56(55.4 \%)$ & $64(63.4 \%)$ & & & \\
\hline \multicolumn{7}{|c|}{$\begin{array}{c}\text { Serious maternal } \\
\text { outcome: }\end{array}$} \\
\hline Yes & $4(4.0 \%)$ & $0(0.0 \%)$ & $1(1.0 \%)$ & \multirow{2}{*}{0.121} & \multirow{2}{*}{0.369} & \multirow{2}{*}{1.000} \\
\hline No & 97 (96.0\%) & $101(100.0 \%)$ & $100(99.0 \%)$ & & & \\
\hline \multicolumn{7}{|l|}{$\begin{array}{l}\text { Adverse drug } \\
\text { reaction: }\end{array}$} \\
\hline Yes & $57(56.4 \%)$ & $23(22.8 \%)$ & $12(11.9 \%)$ & \multirow{2}{*}{$<0.001$ * } & \multirow{2}{*}{$<0.001$ * } & \multirow[b]{2}{*}{$0.041^{*}$} \\
\hline No & $44(43.6 \%)$ & $78(77.2 \%)$ & $89(88.1 \%)$ & & & \\
\hline \multicolumn{7}{|c|}{$\begin{array}{l}\text { Length of hospital } \\
\text { stay: (days) }\end{array}$} \\
\hline Mean \pm SD & $11.57 \pm 10.34$ & $15.43 \pm 11.81$ & $8.79 \pm 7.08$ & \multirow{2}{*}{$0.036^{*}$} & \multirow{2}{*}{0.067} & \multirow{2}{*}{$<0.001$ * } \\
\hline Range & $2.0-70.0$ & $2.0-45.0$ & $2.0-40.0$ & & & \\
\hline \multicolumn{7}{|c|}{$\begin{array}{c}\text { Satisfaction with } \\
\text { treatment }\end{array}$} \\
\hline Yes & $73(72.3 \%)$ & $72(71.3 \%)$ & $84(83.2 \%)$ & \multirow{2}{*}{0.876} & \multirow{2}{*}{0.063} & \multirow{2}{*}{$0.044^{*}$} \\
\hline No & $28(27.7 \%)$ & $29(28.7 \%)$ & $17(16.8 \%)$ & & & \\
\hline
\end{tabular}

P-value': for comparison between ritodrine and magnesium sulfate; P-value ${ }^{2}$ : for comparison between ritodrine and nifedipine; P-value ${ }^{3}$ : for comparison between nifedipine and magnesium sulfate; ${ }^{\star}$ Statistically significant difference.

$(p>0.05)$. However, nifedipine group was the least one in the rate of occurrence of preterm delivery within 7 days from initiation of tocolytic therapy. Similarly, nifedipine group was associated with higher gestational age at delivery and significant prolongation of pregnancy than the other groups. No difference between all study groups regarding the rate of occurrence of adverse neonatal outcomes.

\section{Discussion}

Spontaneous preterm labor (SPTL) and preterm birth (PTB), defined as birth before 37 completed weeks, is the single most important cause of perinatal mortality and morbidity in high-income countries [6].

All the pharmacological agents used to inhibit preterm uterine contractions act by affecting intracellular calcium concentration in the myometrial cells. Some of these agents promote the extrusion of calcium from the cell (beta-adrenergic agents and indomethacin), some displace calcium (magnesium 
Table 3. Neonatal outcomes of the study participants.

\begin{tabular}{|c|c|c|c|c|c|c|}
\hline & $\begin{array}{l}\text { Ritodrine } \\
(\mathrm{n}=101)\end{array}$ & $\begin{array}{l}\text { Mg sulphate } \\
(\mathrm{n}=101)\end{array}$ & $\begin{array}{c}\text { Nifedipine } \\
(\mathrm{n}=101)\end{array}$ & P-value ${ }^{1}$ & $\mathrm{P}$-value ${ }^{2}$ & P-value ${ }^{3}$ \\
\hline \multicolumn{7}{|c|}{$\begin{array}{l}\text { Preterm delivery } \\
\text { before full steroid } \\
\text { dose: }\end{array}$} \\
\hline $\begin{array}{l}\text { Yes } \\
\text { No }\end{array}$ & $\begin{array}{l}36(35.6 \%) \\
65(64.4 \%)\end{array}$ & $\begin{array}{l}30(29.7 \%) \\
71(70.3 \%)\end{array}$ & $\begin{array}{l}30(29.7 \%) \\
71(70.3 \%)\end{array}$ & 0.368 & 0.368 & 1.000 \\
\hline \multicolumn{7}{|l|}{$\begin{array}{l}\text { Delivery within } \\
7 \text { days: }\end{array}$} \\
\hline $\begin{array}{l}\text { Yes } \\
\text { No }\end{array}$ & $\begin{array}{l}16(15.8 \%) \\
85(84.2 \%)\end{array}$ & $\begin{array}{l}17(16.8 \%) \\
84(83.2 \%)\end{array}$ & $\begin{array}{c}6(5.9 \%) \\
95(94.1 \%)\end{array}$ & 0.849 & $0.024^{\star}$ & $0.015^{\star}$ \\
\hline \multicolumn{7}{|c|}{$\begin{array}{l}\text { Gestational age at } \\
\text { birth: (weeks) }\end{array}$} \\
\hline $\begin{array}{c}\text { Mean } \pm \text { SD } \\
\text { Range }\end{array}$ & $\begin{array}{c}32.91 \pm 2.36 \\
25.0-38.0\end{array}$ & $\begin{array}{c}33.31 \pm 2.30 \\
27.0-37.0\end{array}$ & $\begin{array}{c}33.75 \pm 2.70 \\
24.0-39.0\end{array}$ & 0.175 & $0.001^{*}$ & 0.072 \\
\hline \multicolumn{7}{|l|}{ Birth weight: } \\
\hline $\begin{array}{c}\text { Mean } \pm \text { SD } \\
\text { Range }\end{array}$ & $\begin{array}{c}1963.1 \pm 467.3 \\
700-2800\end{array}$ & $\begin{array}{c}2109.9 \pm 495.6 \\
950-3100\end{array}$ & $\begin{array}{c}2097.3 \pm 471.0 \\
850-3000\end{array}$ & $0.034^{*}$ & 0.071 & 0.790 \\
\hline \multicolumn{7}{|c|}{$\begin{array}{l}\text { Prolongation of } \\
\text { pregnancy: }\end{array}$} \\
\hline $\begin{array}{l}\text { Yes } \\
\text { No }\end{array}$ & $49(48.5 \%)$ & $\begin{array}{l}54(53.4 \%) \\
47(46.6 \%)\end{array}$ & $\begin{array}{l}65(64.3 \%) \\
36(35.7 \%)\end{array}$ & 0.398 & $0.010^{*}$ & 0.084 \\
\hline \multicolumn{7}{|c|}{ Adverse neonatal outcome: } \\
\hline No & 79 (78.2\%) & $80(79.2 \%)$ & $85(84.2 \%)$ & 0.864 & 0.280 & 0.363 \\
\hline
\end{tabular}

$\mathbf{P}_{\text {-value }}{ }^{1}$ : for comparison between ritodrine and magnesium sulfate; $\mathbf{P}$-value ${ }^{2}$ : for comparison between ritodrine and nifedipine; $\mathbf{P}$-value ${ }^{3}$ : for comparison between nifedipine and magnesium sulfate; ${ }^{*}$ Statistically significant difference.

sulphate) and some block the entrance of calcium into the myometrial cells (calcium channel blockers). Indomethacin also acts by inhibiting prostaglandin production [7].

Ritodrine is a beta-sympathomimetic drug that is frequently used for the prevention of preterm birth. One of the most important side-effects of ritodrine is pulmonary edema [5]. Magnesium sulfate is widely used as the primary tocolytic agent with maternal side effects includes flushing, nausea, headache, drowsiness, and blurred vision. In addition, magnesium sulfate readily crosses the placenta and may lead to respiratory and motor depression of the neonate. Several observational studies have reported an association of antenatal treatment with magnesium sulfate for preterm labor or preeclampsia with a decreased risk of cerebral palsy in low birth weight or preterm infants [4]. Contrary to ritodrine, nifedipine had minimal effects on maternal pulse rate, systolic and diastolic blood pressure, serum potassium concentrations and blood glucose levels [8].

The characteristics of the study population included in our study were not much different from that of the study held by Cararach et al., 2006 on 80 pa- 
tients divided into two groups to compare the efficacy of nifedipine and ritodrine in prolonging pregnancy beyond 48 hours, 1 week and 36 weeks. The mean maternal age in this study was $26.2 \pm 6.5$ years for the ritodrine group while it was $26.9 \pm 6.1$ years for the nifedipine group. The mean gestational age on admission was $32.1 \pm 2.1$ weeks for ritodrine group and $32.2 \pm 2.2$ weeks for nifedipine group [9].

The result of our study as regard efficacy and safety come in consistent with the study held by Nikbakht et al., 2014 on 100 women, who compared between nifedipine and magnesium sulfate. The study revealed no significant difference as regard 2 days and 7 days effect with $\mathrm{P}=0.51$ and 0.54 respectively. The result was significant as regard severe adverse effects with $\mathrm{P}=0.044$, which was more evident in nifedipine [10].

Also our study comes in consistent with the study held in by Bankatlal et al., 2011 on 120 women [11]. The study compared between nifedipine and ritodrine and revealed that there was no statistically significant difference as regard maternal characteristics $(P>0.05) .2$ days effect was more evident in nifedipine group $(P=0.004)$. No difference as regard 7 days effect and nifedipine had more evident effect as regard prolongation of pregnancy till 37 weeks $(P=0.0371)$. Treatment failure was more in ritodrine $(\mathrm{P}=0.0034)$. Side effects were more in ritodrine $(\mathrm{P}<0.0001)$. Moreover, the study revealed statistically non significant difference between nifedipine and ritodrine as regard gestational age at birth, birth weight and Apgar score, also there was no difference in the incidence of respiratory distress syndrome, intraventricular hemorrhage and neonatal death.

\section{Conclusion}

In conclusion, the present study showed that the use of nifedipine and magnesium sulfate as tocolytic for preterm labor was associated with more prolongation of pregnancy duration than ritodrine. Also maternal side effects profile was fewer with nifedipine and magnesium sulfate than with ritodrine. Nifedipine use was associated with less recurrence of labor pains, less need for additional tocolysis, less duration of hospital stay, and more patient satisfaction.

\section{Conflicts of Interest}

The authors declare that they have no conflict of interest.

\section{References}

[1] American College of Obstetricians and Gynecologists' Committee on Practice Bulletins-Obstetrics (2016) Practice Bulletin No. 171: Management of Preterm Labor. Obstetrics \& Gynecology, 128, e155-e164. https://doi.org/10.1097/AOG.0000000000001711

[2] Cheng, Y., Kaimal, A., Bruckner, T., Hallaron, D. and Caughey, A. (2011) Perinatal Morbidity Associated with Late Preterm Deliveries Compared with Deliveries between 37 and 40 Weeks of Gestation. BJOG: An International Journal of Obstetrics \& Gynaecology, 118, 1446-1454. https://doi.org/10.1111/j.1471-0528.2011.03045.x 
[3] Porto, A.M., Coutinho, I.C., Correia, J.B. and Amorim, M.M. (2011) Effectiveness of Antenatal Corticosteroids in Reducing Respiratory Disorders in Late Preterm Infants: Randomised Clinical Trial. British Medical Journal, 342, d1696. https://doi.org/10.1136/bmj.d1696

[4] Conde-Agudelo, A. and Romero, R. (2009) Antenatal Magnesium Sulfate for the Prevention of Cerebral Palsy in Preterm Infants Less Than 34 Weeks' Gestation: A Systematic Review and Meta-Analysis. American Journal of Obstetrics \& Gynecology, 200, 595-609. https://doi.org/10.1016/j.ajog.2009.04.005

[5] Karaman, S., Ozcan, O., Akercan, F., Terek, M.C., Yucebilgin, M.S. and Firat, V. (2004) Pulmonary Edema after Ritodrine Therapy during Pregnancy and Subsequent Cesarean Section with Epidural Anesthesia. Clinical and Experimental $\mathrm{Ob}$ stetrics and Gynecology, 31, 67-69.

[6] Papatsonis, D., Flenady, V., Cole, S. and Liley, H. (2005) Oxytocin Receptor Antagonists for Inhibiting Preterm Labor. Cochrane Systematic Review, 3, CD004452. https://doi.org/10.1002/14651858.CD004452.pub2

[7] Macones, G.A., Bader, T.J. and Asch, D.A. (1998) Optimising Maternal-Fetal Outcomes in Preterm Labor: A Decision Analysis. BJOG: An International Journal of Obstetrics \& Gynaecology, 105, 541-550. https://doi.org/10.1111/j.1471-0528.1998.tb10156.x

[8] Papatsonis, D.N.M., Lok, C.A.R., Bos, J., van Geijn, H.P. and Dekker, G.A. (2001) Calcium Channel Blockers in the Management of Preterm Labor and Hypertension in Pregnancy. European Journal of Obstetrics \& Gynecology and Reproductive Biology, 97, 122-140. https://doi.org/10.1016/S0301-2115(00)00548-0

[9] Cararach, V., Palacio, M., Martenez, S., Deulofeu, P., Sanchez, M., Cobo, T. and Coll, O. (2006) Nifedipine versus Ritodrine for Suppression of Preterm Labor. Comparison of Their Efficacy and Secondary Effects. European Journal of Obstetrics \& Gynecology and Reproductive Biology, 127, 204-208. https://doi.org/10.1016/j.ejogrb.2005.10.020

[10] Nikbakht, R., Moghadam, M.T. and Ghaneee, H. (2014) Nifedipine Compared to Magnesium Sulfate for Treating Preterm Labor: A Randomized Clinical Trial. Iranian Journal of Reproductive Medicine, 12, 145-150.

[11] Bankatlal, J.P. and Dhabadi, V.B. (2011) Nifedipine versus Ritodrine for Suppression of Preterm Labor and Analysis of Side Effects. The Journal of Obstetrics and Gynecology of India, 61, 534-537. https://doi.org/10.1007/s13224-011-0083-y 